\title{
Axiological Perspectives of Islamic Religious and Political Thought
}

\section{Cristina ARITON-GELAN 1}

\begin{abstract}
This paper aims to examine in terms of axiological some of the most important principles of Islamic religious and political thought. Thus, understanding the relationship between politics, religion and morality plays a fundamental role. For the understanding of the Islamic political life must be correlated with ideas such as: morality, fairness and equity, piety. Thus, the political life and the religious phenomenon are interconnected making a unitary modality of relating to reality. For Islam among politics, religion and ethics there is an indestructible bond. The Islamic moral based on Koran and in our age, the moral reflection is anchored more to the concreteness, reason for which it is transformed into militant ideology.
\end{abstract}

\section{Keywords:}

Muslims, Islamic politics, Koran, imperialism.

${ }^{1}$ Lecturer Ph.D., National Naval Center for Studies and Initiatives in Education, Sport and Traditions, Romania, crisdali@yahoo.com. 


\section{Introduction}

The Islamic politics recognizes the relevance and importance of faith and religious traditions in the development of community. Islam was a political religion even from its beginnings. Thus, Mohamed was not just a prophet, but also a charismatic political leader, and after his death, the caliphs that succeeded him took over his political role. The caliphs were those who, assisted by advisers took decisions upon the new problems that occurred and were appointing the judges that could apply their decisions and run the debates.

The Islamic politics was always the politics of expansion, and the extension of the Muslim territory beyond those from the Arabic peninsula, which means in territories with different traditions, imposed the necessity of a code of unified laws that could compel both the caliphs and the judges and to act according to them. Thus, „starting with eighth century, in some of the biggest cities of the empire a number of scholars were trying to formulate an Islamic Code of laws" [Van de Weyer, 2001: 61], and ,starting with year 900, in the entire Islamic world it started to function a sophisticated system of laws, known under the name sharia" [Van de Weyer, 2001].

\section{Islam - a Political Religion}

The principles of the Islamic Code of laws are exposed in Koran and are considered the only legit ones in the Islamic space to be complied with in the political and social life, as it is considered that ,the person who created us knows better how our social and individual life should run. Practically He offered us the best system after which we, people could live: Islam" [Gülen, 2010: 76]. Therefore, the Islamic political system has at its basis the principles of religion which is considered as being the only true and: „it is true regarding the dogma and uniqueness of Allah, but it is tolerant regarding the practice and legislation" [Al-Qaradawi, 1998: 20].

The principles of the Islamic political life have at their basis religious principles. The principles of political life are based on Koran whose legitimacy is given by the fact that it represents "the word of omniscient and all-seeing, Who knows everything about His Creation" [Gülen, 2010:90] and who „has the capacity to understand and test His Creation gradually while he trains it" [Gülen, 2010: 90]. A conflict between the political and religious forces should produce concern, the 
Muslim leaders think, as the two forces should represent an unique authority, and all the leaders of the Muslim community should become spiritual and intellectual leaders of the state, as Prophet Mohamed was during his life: „During the life of the Prophet ... and the righteous caliphs, the entire society was organized under the form of a unique authority. All the aspects of life - spiritual, moral, political, economic, philosophical, social - were coordinated by control heart. And those who controlled these aspects were the spiritual and intellectual leaders of the state. Those leaders ran the entire Muslim community. But the appearance of the kingdom caused a break to this authority. The political issues remained in charge of the leaders, while the moral and spiritual issues were transferred to theologians and jurists. This break was meant to cause some disastrous consequences for the Muslim community. Worse is the fact that those who had the political power tried to increase their power and influence for controlling the moral and spiritual aspects. ... This conflict between the political and religious powers caused mutual concern and continues to cause even nowadays" [A 'la Mawdudi, 2003: 17 - 18].

\subsection{Principles of Islamic Political Life}

One of the fundamental principles of the Islamic political life which is based on the idea of the necessity of union between spiritual and temporal, unit that fundamentally carries the mark upon the organization of social life: „Islam lays hands on all the spheres of political, economic, social life and does not allow a separation of the spirit from temporal. From this perspective, Islam would be not only a religion for redeeming the individual who is preoccupied with the eternal destiny, but also a normative model of a fortress that bears the mark of sacredness" [Anghelescu , 1993: 77]. The organization of the society is made ,starting from Koran and the knowledge of the Prophet that exceed the contingent and aspire to transcendent" and is based on the „model of ideal fortress that Medina represents during the times of the Prophet" [Anghelescu , 1993: 77], model that ,is extended for some in the society run by so called caliphs ,well dis guised” (ar-raşidun), and for the Shiites in the personality and political work of the Imams" [Anghelescu , 1993: 77]. 
The principles of the social organization are considered to be fundamental truths which have their origin in Koran and that are valid in any age, transgressing the limits related to time: „Islam is a way of life thought by Creator that is not altered in time. The fundamental truths on which the Islam is based are eternal and do not belong to a certain age" [A la Mawdudi, 2003: 6]. They have an unlimited validity as their essence is revealed by divinity: ,it is an eternal truth that the only duty of each creature of God is to cherish Him and obey to His commands. The passing of time could not modify this fact. The realities of life, time and space remain unchained. Therefore, the concepts related to time, as past, present, future, yesterday, today and tomorrow are irrelevant when we practice the Islam" [A 'la Mawdudi, 2003: 6].

Another fundamental principle of Islamic political life has its origins in the traditional understanding of the roots of Islamic jurisprudence. Thus, according to „El-Shafii, a scholar from Mecca, recognized as the father of Islamic jurisprudence, the law must have four roots" [Van de Weyer, 2001: 62] namely: divine revelation of the Koran; sunna or the words and deeds of Prophet Mohamed; consensus and resemblance, in particular cases similar to some of the first three categories, even if they are not stated in this one.

The traditional understanding of the roots of Islamic jurisprudence and the permanent application of it maintain the Muslims in a permanent reporting to the past, the religious principles representing a fundament for the running and organization of the society, as they exceed and are beyond the human imperfect rationing: ,the actual moral condition of Muslim today is the result of those happened in the past. Similarly, their future condition will come from their actual situation. Thus, for examining the current attitudes of the Muslims regarding Islam, we must examine their attitudes from the past regarding it" [A 'la Mawdudi, 2003: 7].

The permanent reporting to past and the origin of each social, political or economic action in the religious principles is by some authors as the expression of a fundamentalism that only a non-Islamic can trace down: „Islam imposes a brutal ecology of the divine message. The prophet receives the revelation that he transmits, without modifications and permission for modification. The text of the Koran is sacred in the physical way; its interpretation, deflected, criticism and interaction are strictly prohibited and punished" [Ungureanu, 2006: 221]. 


\section{Political and Religious Power in Islam}

For Islam among politics, religion and ethics there is an indestructible bond: ,the fortress cannot be run without a leader that should keep into account all the morale commandments and on the other hand the moral behaviour of each citizen depends on the running of the fortress" [Anghelescu, 1993: 76]. The way in which the „fortress is run" must be understood by the model of fortress that the antique philosophers approached in their papers. For instance, „the ideal fortress" that Al-Farabi describes resembles the one that Plato describes in Republica. The ideas about justice, happiness, virtue and types of virtues, common in the papers of philosophers and that influences the moral philosophy of Christian Middle Age may still seem justifying for the political speech of the actual Islam.

The understanding of the Islamic political life depends not only on the understanding of the idea, ideal fortress", but it must be correlated with ideas such as: morality, fairness and equity, devoutness. Thus, the political life and the religious phenomenon are interconnected making a unitary modality of reporting to reality. Noticing this aspect, J. P. Charnay quoted ,it is hard to discern the dimensions of the religious phenomenon in a civilization in which the rightness and legitimacy, moral and dogma, individual behaviours and group behaviours, social relations and political regime make a unique theological - ethical normative assembly" [Anghelescu, 1993: 137].

The Islamic moral is based on Koran and the tradition related to the Prophet. Thus, in Koran, the Islamic community is considered as „the best of communities” [Anghelescu, 1993: 91 - 92], that „advise to right and forbids the evil”, the right meaning, „first of all, the achievement of the ritual obligations and then a series of virtues among whom the social ones play an important role: hospitality, protecting of orphan and weak, respect towards the life of the peer and his belongings, respect for parents, good relations with the family, relationship with neighbors, keeping the word given, etc." [Anghelescu, 1993: 137].

Nabj al-balagha or moral standard, an anthology that contains perceptions formulated by Ali, the first Immam for Shiites and the fourth caliph for Sunnites are fundamental for the reporting to political life of the Shiites and Sunnites. The anthology contains perceptions of ethics and politics, combination that will characterize most of works of 
normative ethics drawn by jurists, theologians and philosophers. This anthology is considered to have been the basis of the Great Discord, meaning the separation of Islam in sects.

In our age, the moral reflection is anchored more to the concreteness, reason for which it is transformed into militant ideology. The strict compliance with the moral code and the model of ideal fortress from Medina become the privileged instruments of some fundamental propaganda, antinationalist and anti-laic: ,any fight considered to be fair - including the movements of national release becomes jihad; any victim of a fight considered to be fair - including the movements of national release is sabid (which also means „witness” and „martyr", in the same time)" [Anghelescu, 1993: 96].

The fairness and equity are essential for the Islamic life, as it is considered that „Prophet Mohamed was known for his fairness even before having been declared a prophet" [Ünal, 2010: 189]. The concept of social fairness, according to the Divine Law, imposes to consider people as free and equal even since their birth, reason for which ,people with high social positions should not take advantage of their position and the weak were not created so that the others take advantage of them" [Ünal, 2010: 190].

There is only one situation in which the individual can consider himself superior to the others, when devoutness is involved. As there is a level of devoutness in Islam, at which the compliance with the perceptions related to moral is determined only by the fear for divinity, hope to be forgiven and the reward promised.

The religious Dogma that stands at the basis of the understanding of Islamic society has at its foundation the awarding of sanctity and eternity to the human interpretations considered as limited and incomplete. The Islamic thinking has in attention issues that transcend time, space and material reality. The Islamic Mysticism or Erfan, unique in the history of the human thinking, represents an elaborate system of knowledge in which the transcendent takes a fundamental role. The Islamic thinkers though consider that for building a realist and durable system of values it is necessary both the reporting to the basic principles of Islam and the reporting to the practical principles of action: „But today, as we want to put Islam in practice and apply its teaching in the material, social and political world, we confront with an intellectual void that can only be remedied if we rely on the 
sources, principles and rules of behaviour of the authentic Islam" [Khatami, 2001: 80 - 81].

The reporting to the practical problems, as Mohamed Khatami noticed, supposes the understanding of the fact that theology must evolve for meeting the practical needs of the actual society: „based on the thinking of Immam, a clergy that is not aware of the requirements of his time won't be able to free the society of the constraints of today, however well intended he would be" [Khatami, 2001: 82].

The Islamic thinkers consider that a practical philosophy, in which the religion and the principles of a fair action are mingled, it is necessary regarding the reporting to the daily life with its implications: „While you have to make sure that there are no religious crimes... you have to focus all your effort for the assurance that when you confront with military, social and political issues, Islam does not seem to lack the practical usefulness" [Khomeini, 1990: 47].

The relation between religion and politics is differently questioned in different periods of the history of Islam and in different areas of the Islamic Empire. It is not neglected that along the time, different ethnical groups came to this empire with their own traditions of organization, with their own institutions, taking part at the central power that they marked with their specific power. For instance, the Persian influence that is exercised upon the central power, upon the entire administration of the Islamic Empire, in the period of Abbasid Caliphate, is a good example in this regard. Since the $9^{\text {th }}$ century, considered an age of „renaissance” for the entire Muslim world, the problem of the relation between religion and power may be understood by two trends: reformist trend, that sees any innovation possible only within the Islam, by restoring its initial purity and laicizing trend that seeks the modernization (sometimes understood as a synonym of westernization) involving a process of dividing the spiritual from temporal. The spreading area of the second trend is very small.

The laicizing trend is based on the tendency of modernization of the society, tendency which is manifested in most of the Muslim countries and which is the expression of faith that solving the real problems of the societies in course of transformation does not depend by the extent in which religion is re-enthroned in all the spheres of life, depending on the existing human and material resources from each society, its economic, political and social development. This sis 
supported also by a part of the intellectuals that have access, together with the Islamic culture, at the occidental culture.

The reformist trend proclaims the necessity of coming back to revelation and the model of fortress from Medina, from the age of the first four caliphs. The reformist movements from the last half of the century have a more focused political character. In this regard, it can be brought to discussion the idea of Islamic „fundamentalism”. Although the Islamic fundamentalism was first applied to the theologians that preached the returning of religion to prototypes, fundamentals, ulterior the term extended to the entire politico-religious movement that refers to a society in which the religious law should be complied with in all its implications. The society instituted in Iran by the Islamic revolution is an image in this regard. The Islamic Reformism proclaims the returning to the great sources of faith and the great models of organization of the fortress. For Muslims, this organization is a democratic one and can be achieved in the highest degree the ideal of justice and social equity.

In the Islamic society the political life is harmoniously mingled with the principles of religious identity, the latter having a fundamental role regarding the maintenance of individual and social dignity, but also of the „social health”: „In all the history of Shiism, the clergy plaid a crucial role in awakening people towards the social pathologies, encouraging them to fight against injustice, awakening their religious identity. In our history, Islam invited people continuously to unity in the religious faith, protecting their individual and social dignity. By the ceaseless callings to social fairness along the history of Islam, the popular religious leaders served as the most intelligent pathologists and healers of the society. That is why the Muslim societies never approached a negative opinion about religion. This contrasts with the occidental societies in which the religious leaders, ungifted and reckless, alienated people from religion" [Khatami, 2001: 152 -153].

\section{Representatives of Political Powers and Decisions at Political Level}

From the institutions point of view, in Islam, the problem of the relation between religion and political power implies two fundamental aspects: on one hand the reporting to the leader position of community, which represents or not a religious appointment, and on the other hand 
the reporting to the representative system of religious power with which the political power may have relations.

If we must report to the first aspect we must have in view that in some Islamic countries the influence of the religious persons, of the institutions related to religion is very big. In Morocco and Saudi Arabia the state leaders are also spiritual leaders. In other countries, such as Tunisia and Lebanon, the great muftiu, whose rank may be closed to what a minister of Cults represents, owns a power which is exercised in domains of a political, economic, and social life. Moreover, the ministry that has attributions related to the administration of religious assets (awqad or babus) or the training of the personnel destined to the Muslim cult, takes an important place within the executive power from many Islamic countries. Besides, the great Islamic universities, such as AlAzhar, in Cairo or Az-Zeituna, in Tunis, exercise a certain political influence that had a bigger or smaller weight factor in different periods.

In other words, if we report to the position of caliph, we notice that this did not have anything sacred, at the beginning, being sacred sometimes due to the popular faith or the actions of the "scholars" (ulema). The latter will form the representative system of religious power on which the power is based on, in some ages, and that will become to influence if not substitute sometimes.

The Caliph is the supreme chief of the Muslim community. The word „khalifa” means „successor” or „substitute” and appears in the expression Khalifa(t) rasul Allah, which is translated by "successor (substitute) of Allah's messenger". Thus, caliph is the one who follows after Muhammad, not as a Prophet, as this mission ends with him, but as the capacity exercised at Medina, as leader of the religious community.

The Caliph represents a sort of spiritual leader of Muslims, as Pope is the spiritual leader of Catholics and the institution of caliphate remains the symbol of the unity of Muslim community: ,in 1175, when Saladin became a master over Egypt and Syria, he required and received an appointment from the caliph at that time, Al-Mustadi, and the same thing happened later, with different princes, kings and sultans" [Anghelescu, 1993: 87].

The Caliph keeps a symbolical supremacy even when power becomes almost a fiction. The Pan-Islamic organizations appeared in the last decade only try to find a substitute for him. 
In present the title of amir al-mu minin „prince of believers”, that the caliphs have since the time of Omar, is assumed by the king of Morocco, sarif, which means belonging to a family that has the roots in that of the Prophet's.

Immam is the leader of praying in common and also the cleverest member of the group, as the ritual prayer requires a certain amount of knowledge from the person who chairs it. Although he isn't required a special qualification, in practice, any community that owns a mosque appoints an immam that is remunerated and may have some attributions related to the administration of the issues of the respective community. The word immam can be translated with „sign”, „indicator”, but also with „model” or „leader”.

In the Sunni Islam the term of immam is used for appointing the caliph as spiritual leader of the community, who is in charge of chairing the prayer in common. The term has particular connotations in the Shiite doctrine where this is considered a descendent of Ali and Fatima, the daughter of the Prophet, and is recognized as spiritual and temporal leader of the community. For the Shiite sects, imam is considered carrier of the „Muhammad Light”, reason for which is impeccable and infallible [Anghelescu, 1993: 89]. The relationship between Immams is spiritual and allows the passing of „Light” from an Immam to another, each of them becoming ma'sum, which means ,impeccable” gaining the authority of interpreter of Divine Law.

Molla (b) or mawla, translated with „master” or „ruler” represents at Shiites the descendants of the Prophet, who must be in the same time inspired interpreters for Koran and Hadith. Mollah is in the same time teacher and religious leader of a locality or an area.

Ayatollah or Ayatu (A)llah, in Arabic is translated with ,sign of God" and is a title related to a hierarchy used by Immam-Shiites with twelve Immams, which means the predominant Shiite orientation in Iran.

Mujtahid is the holder of a level of some religious knowledge, who is recognized by the entire mass of the believers and who has an important role in the political, social and economic life of the country.

Ulema, ulama' or ulema' is the plural form of the term alim and designates the idea of „literate” or „scholar". This designation is associated with „scholar who knows the tradition”, who is first a jurist, then a theologian. The term appears at plural form as these scholars 
form a body that is delegated „consensus” of the community and that has the decision in problems related to dogma and legislation, in conformity with the Koran and tradition [Anghelescu, 1993: 90]. In different periods, the respective body of scholars had an official or semiofficial statute, becoming a type of caste that supports the power and which is protected by it. The authority of these scholars is related by the famous faculties of theology within which they are grouped: Al-Zahar in Cairo, Az-Zaytuna in Tunis, Al-Qarawiyyin in Fez, and for Shiites Qum in Iran and Najaf in Iraq.

Mufti is ,the one who offers an opinion, an advice regarding the religion", which means a fatwa. Therefore he represents the qualified person who answers at a solicitation from the judge (cadi) or a certain member of the community. The opinion expressed by him must be based both on the profound knowledge of canonical legislation and that of precedents accumulated in its application at particular cases [Anghelescu, 1993: 90 - 91). In some modern Muslim states there is the tendency of limiting the validity of decisions of the muftiu to problems related to the statute of family (as marriage, divorce or succession), the rest of the problems being regulated by codes that have their model in the European ones. In other Muslim countries the authority of muftiu is great, couldn't be considered as the equivalent of the Minister of Cults. In the countries in which the Muslim communities have minority, as Romania, muftiu is considered as chief of the respective community, the one who represents the community in relations with other communities and with authorities.

Cadi or qadi (in Arabic) means ,judge” and represents the person who, in conformity with the Muslim legislation is able to decide for all the problems related to civil and penal legislation. In the ottoman period, cadi could exercise some administrative attributions in the area of his jurisdiction. This person must be a good knower of legislation and a person with an irreproachable morality: „he mustn't receive gifts, mustn't trade - neither directly, nor by intermediaries. His judgment is definite and without appeal" [Anghelescu, 1993: 91]. The existence of some codes elaborated after the European models in some Muslim countries limits the domain of action of the cadi to some problems of family law. 


\section{Relation Islam - Occident}

„We still suffer from the identity diluted by «intoxication of occident)" [Khatami, 2001: 80] declared in 2001 the President of Islamic Republic of Iran, Mohammad Khatami, interpreting the idea of freedom that the Occident promotes at a world scale as the mask of a politics globally dominated. Having the same meaning, quoting Ruhollah Khomeini, Mohammad Khatami referred to the practical laws of Islam and their special importance: „We must realize the practical laws of Islam, untouched by the deceiving Occident, invading East and their diplomatic modalities, globally dominated. For as long as theology is closed in books and in the soul of the clergy, no evil could happen to the devouring forces of the world. ... Our actual methods to lead the society seem to be changed in the years to come. And the human society will use the subjects which the Islam confronts with" [Khatami, 2001: 82].

As the Islamic political system is seen by the Islamic thinkers as a successful one and that it is based on the religion of truth: „The truth is that the real motif for the success of Islam is different from what those from Occident suggest. ... In the early period of the mission of the Prophet (may Allah bless and give alms to him), while he was still propagating the Islam in Mecca, only a small number of people understood the importance of his message. This was understood and appreciated only by those who had a decent reasoning and whose thinking was not touched by the tribal prejudices. Also, those who had the moral courage to sacrifice their life for the religion of truth could adopt Islam against all obstacles [A 'la Mawdudi, 2003: 11].

The political system of the Occident supposes a system of values and thinking that are totally different from the Islamic one, for this reason it is perceived as a threat: „there is a system of values and thinking that we have to understand and learn how to work with it. Here we confront with our philosophical and moral opposition, not just with a political opponent ... Rejecting the Occident, we want to set us free by its political, mental, cultural and economic dominance, because we, the Muslims are fundamentally different from them in the vision upon the world and values. This is for understanding our divergences and for rejecting the dominance of the opponent, we have no other choice than to appreciate and understand the Occident precisely and objectively" [Khatami, 2001: 145 - 147]. 
The occidental imperialism is seen as a danger for the political thinking of Islam, which is owed to the mask that the Occident uses in the on behalf of independence and freedom, science and culture, concepts that, in the opinion of Islamists prove to be emptied of any substance: „In its political embodiment, the Occident does not want that we - or any other state - to be independent, free and owners of our own fate. Because if a quality of occidental imperialism violates others' territory and exploits their economy, the next quality is the dominance of the world of ideas. The Occident propagates a vision upon the world in which it attract the pray for subjugating it" [Khatami, 2001: 144] and in the „political confrontations the enemy uses the mask of science and culture for deceiving us. In reality, though, his only wish is to allure a state to surrender to its wishes and serve its interests and take over all the resources of the victim for serving the imperialist power" [Khatami, 2001: 144].

The persuasion in the political subjugation seems to be the ambition of the occidental power, consider the Islamic thinkers when it comes to the problem of development and civilization of other states: „When the colonial powers violate other states they never recognize that their goal is to rob the resources of the victims or politically subjugate them. In exchange, making an abuse of their persuasive powers, they try to cover their crimes by words and ideas that are accepted by the entire humanity. From ancient times, the colonial powers used the excuse of development and civilization of other countries in order to invade them and steal their lands. Today, as before the political motto of the Occident remains defending of liberty, human rights and democracy [Khatami, 2001: 144 - 145].

\subsection{About the Idea of Freedom}

The idea of freedom represents in the conception of the Islamic thinkers the fundament that sustains the political occidental system: „We must keep in mind that in the occidental civilization is found the idea of „freedom". This is the most beloved value of humanity from all times, and, to be honest, the march of occidental civilization from the Middle Age to the modern centuries eliminated many superstitions and broke chains in thinking, politics and society. The Occident freed the people from the handcuffs of many oppressive traditions. It successfully 
eliminated the divinization of regressive thinking which was imposed to the masses on behalf of religion" [Khatami, 2001: 147]. Even the use of religion in the implementation of the political system must be reported to the idea of freedom: „When we stand up to our opponents on behalf of rejecting the Occident and defending the religion, if we repress freedom, we will cause a big catastrophe. But if rejecting Occident means to criticize its opinion on freedom, humanity and world, then we would have accomplished the fundamental, historical mission" [Khatami, 2001: 147].

According to the Islamic thinking, the Occident does not know the real freedom as it uses his deepest and strongest instincts to impose a trend, without keeping into account the high morality and spiritual growth: „It is true, people are not attracted by anything else as they are attracted to freedom and never did they scarify so much for reaching a goal, as they did for freedom. Today people are offered a system that invites them to eat and drink as they like, to dress and talk as they want and to think freely. Simultaneously, the goal of life in such a system is represented by property and power, both seen as serving for the biggest and hallowed purpose of humanity, the freedom, using the deepest and strongest human instincts to consolidate its position. This thing is deceitful, as despite everything it pretends the Occident is far from accomplishing the real freedom. We want a system based on abstinence and high morality which is accomplished by crucial efforts and courage in commitment to moral and spiritual upraising. This is the real freedom, and people need to be taught to see it differently" [Khatami, 2001: 78].

According to the Islamic thinking, both the idea of individual freedom and social freedom may be found in the Koran message and teaching of the Prophet. The statement upon the buman rights in Islam from 1981 is based on texts from Koran and hadith, ,that serve as guaranty for the dignity of the human person, racial indiscrimination, unity and dignity of family, helping, freedom of conscience, protection of other's assets, inviolability of the residence, care for the poor, right to learning and health" [Anghelescu, 1993: 97].

\section{Islam - a Model for Exercising the Political Power?}

Islamic political system analysis of the made by non-Muslim states that sometimes Islam is fatalist, fanatic, violent or aggressive. This 
type of interpretation is due to the fact that in the conception of Muslim thinkers, and Abu'l-Fazl Ezzati is one of them, on one hand Islam represents a complete way of life, in which there is no division of human activities, the political system being an integrant part of religion. On the other hand, Islam is considered a universal system that includes the eternal values, protecting in the same time the rights of any person, reminding him/her though constantly of the obligation he/she has towards himself/herself and towards society [Ünal, 2010: 192].

In this context, the Islamic thinkers consider that the most complete development of human potential may be obtained by the implementation of the Islamic principles, that refer first of all to the spiritual and moral development. The Islamic principles are considered as being perfect, as they come from Divinity, this is why they impose imperatively. In this regard, Islam has come to establish with authority what is allowed and what is forbidden, on behalf of the concept of divinity: „Islam has established the authority that has the right to decide what is allowed and what is forbidden, taking it from the people's hands, whatever their position in the hierarchy of the religion is, or in the hierarchy of the state and making it an exclusive competency of Allah. Neither the apostles nor the monks, neither the kings nor the sultans have the right to forbid a thing for ever to the servants of Allah. The person who did that thing means that he exceeded his attributions and raise against Allah's rights to establish orders for people, and the person who accepted that thing from them and followed them means that he made them associates of Allah and this is considered polytheism" [AlQaradawi, 1998: 16 - 17].

The rigidity of Islamic thinking is seen from the modality in which it is conceived the idea of divinity, namely Allah, thought and interpreted according to the Islamic doctrine that is the only true divine principle. Moreover, this divine principle dictates on what is appropriate or not in the development of social life, as well as the understanding of political system. Having as reference certain lines from Koran „the specialists in jurisprudence $(f i q h)$ figured out clearly that only Allah himself is entitled to allow and stop, by His Book or by His Messenger and that their mission is limited at the presentation of what Allah decided to be allowed or stopped" [Al-Qaradawi, 1998: 18].

As fundament of Islamic political thinking, religion had and has in the conception of the Muslim thinkers a fundamental role in 
approaching the most pertinent modality of interpretation of social order: „Today we may observe around us the ruin of the systems made by human being. Feudalism, capitalism, socialism and communism fell down gradually or are in ruins, leaving behind only complaints and angriness. Though, Islam is almost close to us and never lost its original strength. The West is aware of it as more of the hearted people from there, gladly welcome the Muslim guides and foretellers. Even some churches agreed to help Islam in a way or another. The humankind is leading to a better understanding of Islam and there is a spread belief according to which Islam may solve any problem" [Al-Qaradawi, 1998: 76].

Although it is based on "prescriptions genetically fixed by a religion that changed too little" [Ungureanu, 2006: 219], the Islamic political doctrine ,always protected from a real Reform, stands with undiminished authority above the social world of Islam" [Ungureanu, 2006: 219], being in the same time the consequence of a vision dictated by the idea of obedience and assimilation- specific to imperialism that Islam proves to have -, as well as by the consequence of a religious legitimacy, based on a prophetic program in which, besides the idea of uniqueness - uniqueness of Allah -, it may be included the declared idea of a religious tolerance, considered in a certain regard, ,a sociopolitical characteristic specific to Islam" [Gülen, 2010: 38], that justifies the possibility of understanding of alternative, which means a different system, a different thinking.

\section{Conclusion}

The most important principle of Islam, in terms of axiological, concerns that political action is a way that can be achieved the return to the ideal state based on religious principles. The mixture of the religious, traditions and jurisprudence is considered to be the way to maintain of the individual and social dignity and also of the social health. For, according to Islamic thought, morality and spirituality are the most important concepts when it comes to community development and politics must be permeated by these two concepts. The very idea of freedom can be expressed genuine, their only light, hence the criticism of the idea of freedom promoted by the Occident, which seems to be a real freedom, but isn't. Or, axiological speaking, failure limits in such an interpretation is the sure way to ideology. 


\section{References}

A 'la Mawdudi, A. (2003). Islam today. Bucuresti: Taiba Foundation Press. Al-Qaradawi, Y. (1998). Allowed and forbidden in Islam. Timisoara: Islam Press.

Anghelescu, N. (1993). Introduction in Islam. Bucuresti: Encyclopedic Press.

Gülen, M. F. (2010). Questions and answers about Islam (vol. 1). Bucuresti: RAO International Publishing Company.

Khatami, M. (2001). Islam, dialogue and civil society. Bucuresti: Argus Press.

Khomeini, R. (1990). Book of Light [Sahifey-e Noor] (vol. 21). Teheran: Mrkaz-e Madark Anghlab-e Islami.

Ungureanu, T. (2006). The war of ages, occidental decline and Islamic siege. Bucuresti: Humanitas Press.

Ünal, A. (2010). Life in Islam. Bucuresti: RAO International Publishing Company.

Van de Weyer, R. (2001). Islam and Occident. A new political and religious order after September $11^{\text {th }}$. Bucuresti: ALLFA Press.

\section{Biodata}

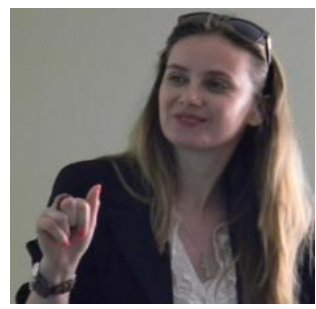

Cristina ARITON-GELAN is lecturer Ph.D. at the Faculty of Law and Administrative Sciences within „Ovidius” University from Constanța. She participated in National and International Conferences in the fields of philosophy, communication, semiotics, sociology, geopolitics and she has published over 50 scientific articles in edited volumes and journals. In 2012 she published the book Angst and Cultural Neuroses. She was editor of the magazine "Culture: International Journal of Philosophy of Culture and Axiology", editorial office secretary of "Communication and Marketing Journal" and web editor of the European Journalism Observatory. Since 2010 she is member of the "Ion Conea" Association of Geopolitics. 